\title{
MANAJEMEN PENGELOLAAN KAWASAN BERSEJARAH DI DESA SODITAN, LASEM, REMBANG
}

\author{
Heritage Asset Management in Soditan Village, Lasem, Rembang
}

\author{
Wakhidah Kurniawati ${ }^{1}$, Retno Susanti ${ }^{1}$, Nurini ${ }^{1}$, Rina Kurniati ${ }^{1}$, Sugiono Soetomo ${ }^{1}$, M Rizki Islami ${ }^{1}$ \\ 11 Departemen Perencanaan Wilayah dan Kota, Universitas Diponegoro \\ Email: wakhidahkurniawati3@gmail.com
}

\begin{abstract}
Abstrak
Desa Soditan merupakan salah satu desa warisan sejarah yang terletak di pusat Kecamatan Lasem, Kabupaten Rembang, Jawa Tengah. Desa Soditan terletak di sepanjang Sungai Babagan Lasem dan Jalur Pantura yang dahulu disebut sebagai jalan raya pos De Groote Post Weg yang dibangun oleh Daendels. Di desa ini terdapat kawasan heritage Pecinan dengan Klenteng $\mathrm{Cu}$ An Kiong-nya, rumah candu Lawang Ombo, budaya khas Kopi Nglelet dan Batik Lasem. Saat ini kawasan bersejarah ini mengalami masalah degradasi fungsi, rusaknya bangunan khas Cina, dan semakin hilangnya sense of place kawasan. Untuk itulah, penelitian ini bertujuan untuk merumuskan konsep manajemen pengelolaan kawasan berdasar karakteristik khas kawasan. Adapun tahapan yang dilakukan dalam penelitian ini adalah mengeksplorasi potensi masalah Desa Soditan terkait pengembangan kawasan bersejarah, dan merumuskan konsep manajemen pengelolaan kawasan yang sesuai. Konsep manajemen pengelolaan yang yang ditawarkan adalah kemitraan antara pemerintah, swasta, dan masyarakat. Dari konsep manajemen pengelolaan yang disusun diharapkan dapat mendukung pelestarian cagar budaya di Desa Soditan di sektor pariwisata, memperkuat sense of place kawasan bersejarah, serta mampu mendukung perekonomian daerah dan masyarakat lokal.
\end{abstract}

Kata kunci: perancangan kawasan, desa wisata, tembakau

\section{PENDAHULUAN}

Heritage asset management adalah suatu upaya pengelolaan warisan budaya yang bersifat fisik ragawi (tangible heritage), non ragawi (intangible heritage), dan abstract berupa norma masyarakat (BPPI, 2019). Manajemen benda-benda warisan budaya ditujukan untuk mengelola dan memelihara nilai-nilai warisan budaya. Juga untuk menata dan mendesain ulang bangunan-bangunan dan kawasan budaya, serta dimungkinkan untuk mempromosikan dan menjual potensi yang dimiliki benda-benda warisan budaya tersebut. Banyak kawasan bersejarah di Indonesia yang harus memperhatikan manajemen peninggalan sejarahnya supaya bisa bertahan, terkelola dengan baik, dan bisa memiliki nilai jual untuk pengembangan kawasan, termasuk di Desa Soditan, Kecamatan Lasem, Kabupaten Rembang.

Kecamatan Lasem di Kabupaten Rembang merupakan salah satu kota tua di Pantai Utara Jawa Tengah yang menyimpan layer sejarah panjang mulai dari era Kerajaan Singosari tahun 1351, Kerajaan Majapahit tahun 1466, masuknya budaya Cina tahun 1413, masuknya Islam tahun 1469, dan masuknya budaya Eropa (Kusnawan, 2011). Peninggalan sejarah yang ada menjadikan Kecamatan Lasem sebagai kawasan cagar budaya, pusat akulturasi 
budaya dan juga terkenal sebagai "The Little Tiongkok" karena keberadaan permukiman Cina-nya.

Desa Soditan sendiri memiliki kedudukan penting dalam perjalanan sejarah Kecamatan Lasem karena merupakan layer pertama yang menjadi cikal-bakal perkembangan Lasem. Desa Soditan merupakan pintu masuk masyarakat Tionghoa dalam memulai pertumbuhan permukiman Cina di Kecamatan Lasem. Permukiman Cina yang ada semakin lama semakin berkembang, ditandai dengan adanya Klenteng $\mathrm{Cu}$ An Kiong yang merupakan klenteng tertua di Pulau Jawa. Selain itu, di Desa Soditan juga terdapat akulturasi budaya diantara Pribumi, Cina, Islam, dan Eropa. Pertumbuhan ekonomi dan budaya di Desa Soditan juga dipengaruhi oleh keberadaan jalan raya pos De Groote Post Weg yang menjadikan Desa Soditan sebagai pusat kegiatan ekonomi yang didominasi dengan permukiman Cina.

Sayangnya Kecamatan Lasem mengalami kemunduran setelah kemerdekaan Indonesia. Hal ini salah satunya disebabkan oleh menurunnya populasi penduduk Cina. Kondisi tersebut tentunya berdampak pada situs-situs peninggalan sejarah di Desa Soditan yang kemudian mengalami kerusakan, semakin tak berfungsi, tak terawat, hilang, dan budaya yang terlupakan. Kondisi ini memicu hilangnya sense of place kawasan dan mengakibatkan memudarnya karakteristik khas kawasan Desa Soditan. Oleh karena itu, tulisan ini berupaya mengeksplorasi upaya pengelolaan kawasan bersejarah di Desa Soditan yang masih tersisa. Upaya pengelolaan yang akan dirumuskan adalah konsep manajemen pengelolaan terhadap situs peninggalan sejarah yang ada supaya cagar budaya di Desa Soditan dapat dilestarikan dalam sektor pariwisata dan memperkuat sense of place kawasan bersejarah, serta mampu mendukung perekonomian daerah dan masyarakat lokal.

\section{PERTANYAAN PENELITIAN}

Adapun pertanyaan penelitian yang muncul adalah: "Bagaimana konsep manajemen pengelolaan terhadap cagar budaya di Desa Soditan agar sesuai dengan karakteristik khas kawasan?"

\section{TINJAUAN PUSTAKA}

Warisan budaya merupakan hal signifikan dalam kehidupan perkotaan dan proses pembangunan. Tujuan dari konservasi kawasan bersejarah adalah untuk meningkatkan kualitas lingkungan dan memastikan kontinuitasnya sebagai tempat yang diinginkan untuk hidup, serta menghubungkannya dengan budaya yang ada. Konservasi bukan hanya sekedar pertimbangan arsitektural, tetapi juga penyelesaian masalah ekonomi dan sosial. Budaya adalah bagian penting dari kehidupan manusia dan perkotaan, yang dinamis yang menghubungkan kesinambungan masa lalu ke masa kini dan ke masa depan (ICOMOS, 1999).

\section{Heritage Asset Management}

Aset cagar budaya adalah bagian integral dari komunitas dan lingkungannya. Mereka adalah bukti nyata dari asal usul budaya negara dan kemajuannya, dan fondasi sejarah yang menjadi dasar banyak keputusan tentang masa depan masyarakat. Aset cagar budaya secara khusus didefinisikan sebagai "lansekap, tempat, pekerjaan, bangunan atau peninggalan arsitektur, arkeologi, estetika, sosial, budaya, teknis, ilmiah atau signifikansi warisan alam" (NSW Heritage Office, 2004). 


\section{Sense of place}

Sense of place adalah rasa ruang yang dipengaruhi oleh keterikatan masyarakat atau pengunjung terhadap ruang (social and environmental bonding). Selain itu rasa ruang sangat dipengaruhi oleh identitas tempat, dan kebergantungan masyarakat terhadap tempat. Sehingga untuk meningkatkan sense of place perlu menciptakan dan menguatkan identitas ruang yang pernah ada di masyarakat (Punter, 1991 dalam Montgomery, 1998; Liu dan Cheung, 2016; Ramadhani, Faqih, dan Hayati, 2018).

\section{Konsep Pengelolaan Kawasan Bersejarah}

Di dalam Rencana Tata Bangunan dan Lingkungan Kawasan (RTBL) Pusaka Lasem 2019 disebutkan bahwa pola kerjasama penanganan RTBL dapat berupa build operate transfer (BOT), build own operate transfer (BOOT) maupun build lease transfer (BLT).

Built Operate Transfer (BOT) merupakan salah satu model manajemen pengelolaan kawasan yang mengoptimalkan kerjasama yang dilakukan oleh pemerintah dan swasta untuk melakukan suatu proyek. Kerjasama BOT biasanya dipergunakan khususnya untuk pelayanan skala besar atau pembangunan baru. Selain itu kerjasama BOT biasanya juga dilakukan apabila pemerintah membutuhkan dana yang cukup besar untuk melakukan pembangunan dengan jangka waktu yang cukup panjang. Pada kerjasama BOT ini, lahan yang digunakan untuk pembangunan dimiliki oleh pemerintah sedangkan biaya pembangunan disediakan oleh swasta.

Public Community Partnership (PCP) merupakan salah satu model manajemen pengelolaan suatu kawasan dimana dalam model ini melibatkan pemerintah sebagai pihak pemberi dana sedangkan pihak pengelola dan penyedia oleh masyarakat.
Konsep manajemen pengelolaan PCP selain menghasilkan profit bagi pemerintah, juga dapat memberdayakan dan mengembangkan ekonomi masyarakat yang terlibat. Sehingga diharapkan melalui model kerja sama ini, masyarakat dapat memperoleh manfaat dan peningkatan kesejahteraan

\section{METODE}

Tujuan dari penelitian ini adalah merumuskan manajemen pengelolaan kawasan bersejarah di Desa Soditan Lasem Rembang dengan berbasis pada kemitraan antara stakeholder.

Tahapan yang dilakukan dalam penyusunan desain ini yaitu review kebijakan pengembangan kawasan, perumusan potensi masalah kawasan, dan perumusan konsep manajemen pengelolaan kawasan dengan menggunakan data-data yang tersedia.

\section{REVIEW KEBIJAKAN PENGEMBANGAN DESA SODITAN KECAMATAN LASEM}

Pengembangan Desa Soditan, Kecamatan Lasem sebagai salah satu desa cagar budaya tertuang dalam Peraturan Bupati Rembang Nomor 47 Tahun 2019, tentang Rencana Tata Bangunan dan Lingkungan Kawasan Pusaka Lasem, Kecamatan Lasem Kabupaten Rembang. Sebagian isi dari peraturan terkait pengembangan dan penataan Desa Soditan adalah sebagai berikut:

- Rencana delineasi RTBL Kota Pusaka Lasem seluas kurang lebih $60 \mathrm{Ha}$ meliputi Desa Gedongmulyo, Desa Soditan, Desa Karangturi, Desa Babagan, Desa Dorokandang dan Desa Sumbergirang (Bab III, pasal 6, ayat 1).

- Desa Soditan di tepi Sungai Babagan masuk dalam zona 2 (Bab III Pasal 7 Huruf c)

- Penanganan sekitar Pecinan meliputi revitalisasi permukiman Pecinan 
dengan memperbaiki infrastruktur kawasan; melestarikan bangunan cagar budaya klenteng dan bangunan pusaka lainnya; dan mengarahkan kawasan untuk menjadi pusat ekonomi (Bab IV, pasal 10 , ayat 3 ).

\section{PERUMUSAN POTENSI, MASALAH, DAN KONSEP MANAJEMEN PENGELOLAAN KAWASAN BERSEJARAH}

Desa Soditan Lasem menyimpan potensi bersejarah yang dapat dikembangkan menjadi kawasan cagar budaya dan pariwisata. Menurut sejarah, Desa Soditan adalah cikal bakal dari Lasem. Terdapat Klenteng $\mathrm{Cu}$ An Kiong, dibangun sekitar abad ke-16 oleh masyarakat Tionghoa yang berlabuh di Lasem dan menjadi klenteng tertua di Lasem, Rembang. Sementara itu, permukiman Cina yang terdapat di sekitar Klenteng $\mathrm{Cu}$ An Kiong telah ada sebelum dibangun Klenteng tersebut. Arsitektur rumah orang Tionghoa di daerah Lasem mempunyai bentuk yang unik, yakni percampuran arsitektur Belanda (Indische Empire) dan interior yang masih khas Tionghoa (ruang sembahyang) serta barang-barang kesenian pribumi seperti Gamelan, Wayang, dan Keris (Islami dkk, 2021).

Sementara itu, Sungai Babagan Lasem yang merupakan batas fisik Desa Soditan, adalah urat nadi Lasem tempo dulu. Pada awalnya Sungai Babagan Lasem merupakan salah satu jalur transportasi penting bagi masyarakat Lasem untuk mendistribusikan barang menuju keluar ataupun masuk daerah Lasem. Keberadaan sungai ini turut membentuk desain morfologi Lasem. Sungai inilah yang menghubungkan daerah pedalaman dengan daerah pesisir. Hal tersebut membuat Sungai Babagan Lasem menyimpan sejarah dalam perkembangan daerah Lasem. Hal ini menjadi salah satu potensi bersejarah yang dapat dikembangkan pada kawasan penelitian.

Hal lain yang menjadi potensi kawasan adalah keberadaan warung Kopi Lelet. Warung kopi lelet merupakan tempat yang memiliki sejarah, mayoritas berlokasi di belakang Klenteng Cu An Kiong. Dahulunya rumah kopi lelet menjadi tempat berkumpulnya masyarakat Tionghoa dan pribumi untuk bertukar informasi atau sekedar menikmati kopi sambil melakukan budaya lelet. Budaya ini merupakan budaya membatik rokok dari ampas kopi.

Batik Lasem, wujud akulturasi budaya Cina dan Jawa. Kawasan bersejarah ini merupakan salah satu daerah yang menjadi penyebaran dan perkembangan Batik Lasem. Batik Lasem ini merupakan salah satu wujud akulturasi dari budaya Cina dan Jawa yang ditandai dari motif khas dari Batik Lasem (Islami dkk, 2021).

Sedangkan masalah yang ada di kawasan adalah semakin berkurangnya sense of place atau "rasa" dari Kawasan Pecinan Lasem. Hal tersebut dimulai pada awal abad ke-20 dimana Kawasan Pecinan di Lasem sudah stagnan. Kelenteng tidak populer lagi bagi angkatan muda Lasem. Beberapa rumah tinggal Tionghoa di Pecinan Lasem sudah mulai berubah, rusak dan hilang dikarenakan trauma dengan rezim penguasa, kerusakan fasade bangunan sepanjang jalan pantura yang dilebarkan, pindahnya pemilik rumah karena ekonomi Lasem yang semakin sepi, mahalnya biaya perawatan rumah tradisional, dan tawaran untuk menjual rumah yang lebih menguntungkan daripada merawat rumah (Purwanto, 2018). 


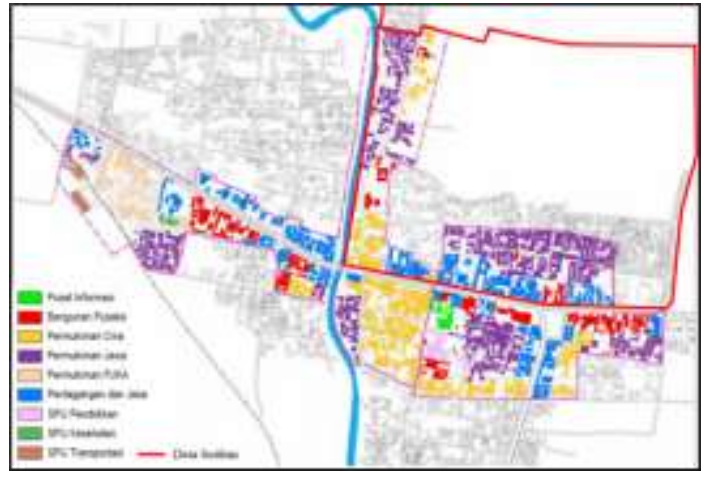

Gambar 1. Titik Bangunan Bersejarah Desa Soditan Sumber: DED RTBL Kawasan Pusaka Lasem Kabupaten Rembang, 2017

Dari analisis potensi masalah yang dilakukan, maka kemudian diusulkan desain ruang kawasan yang mendukung wisata budaya sejarah (cultural heritage tourism). Ruang-ruang yang diusulkan untuk meningkatkan sense of place kawasan, sekaligus untuk meningkatkan perekonomian kawasan meliputi: pelestarian Klenteng dan Bangunan Lawang Ombo yang ada di kawasan, pelestarian hunian tradisional Cina dan peningkatan fungsi menjadi homestay atau kegiatan perdagangan dan jasa, penataan koridor warung kopi lelet, penghidupan tepi Sungai Babagan Lasem dengan konsep susur sungai, serta perlunya pembangunan Museum Lasem untuk mengedukasi pengunjung dan generasai muda yang ada. Penataan ini tentunya harus memperhatikan panduan di RTBL Kawasan Pusaka Lasem, 2019 karena ada aturan wajib dan aturan anjuran yang harus diperhatikan di Lasem (Pasal 39, ayat 1).

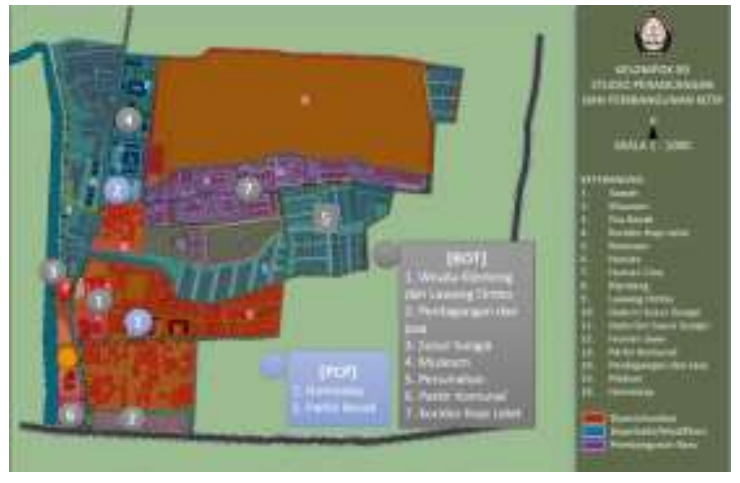

Gambar 2. Peta Rencana Konsep Pengelolaan Kawasan Bersejarah Desa Soditan

Sumber: Studio Perancangan dan Pembangunan Kota PWK Undip, Kelompok B5, 2021

\section{MANAJEMEN PENGELOLAAN KAWASAN}

Konsep manajemen pengelolalaan kawasan bersejarah Desa Soditan yang diusulkan berupaya untuk meningkatkan Sense of place Desa Soditan yang mulai menghilang dari waktu ke waktu. Desa Soditan memiliki potensi yang bisa dikembangkan sebagai sebuah kawasan cultural heritage tourism yang nantinya selain mendukung pelestarian kawasan juga menjadi nilai tambah bagi kawasan dan masyarakat (McKercher, dan Du Cros, 2002).

Pengelolaan kawasan bersejarah Desa Soditan saat ini masih menggunakan pengelolaan konvensional oleh penanggung jawab masing-masing bangunan. Klenteng $\mathrm{Cu}$ An Kiong yang sampai sekarang masih dipergunakan untuk kegiatan ibadah umat Konghucu, dikelola oleh para umat Konghucu dan dikelola untuk wisata tetapi terbatas serta dengan izin oleh juru kunci disana. Sama halnya pengelolaan Omah Candu/Lawang Ombo dikelola oleh keturunan Lim Cui Sun sebagai orang yang memiliki Lawang Ombo pada abad 18-an. Sayangnya bangunanbangunan bersejarah lain yang dahulunya rumah sekarang banyak ditinggal oleh pemiliknya. Terdapat beberapa bangunan yang terbengkalai tidak berpenghuni dan tidak dikelola oleh ahli warisnya sehingga menyebabkan bangunan tersebut banyak yang rusak.

Usulan konsep pengelolaan kawasan yang dinilai sesuai dengan RTBL adalah bentuk kerja sama BOT/ Build Operate Transfer (RTBL Bab VI, pasal 42, ayat 3). Konsep tersebut menjadi salah satu pilihan pengelolaan serta pembiayaan 
pembangunan dimana pihak swasta menyediakan sendiri modal atau pendanaan proyek, termasuk menanggung pengadaan material, peralatan dan jasa lainnya yang dibutuhkan untuk kelengkapan proyek. Untuk itu, pihak swasta memiliki hak untuk mengoperasikan dan mengambil manfaat ekonomi pembangunan proyek tersebut (manajemen dan operasional) sebagai penggantian dari seluruh biaya yang telah dikeluarkan dengan jangka waktu tertentu.

Hal lain yang diusulkan adalah setiap kawasan di Desa Soditan menerapkan jenis kerja sama PPP/ Public Private Partnership dimana pemerintah bekerja sama dengan pihak swasta dalam setiap proses manajemen dan pembangunan di Desa Soditan. Pemilihan konsep ini diambil dikarenakan saat kontrak habis, aset akan kembali ke tangan pemerintah. Hal ini untuk menghindari orientasi pada profit yang di khawatirkan dapat menurunkan sense of place kawasan dengan pengembangan aktivitas baru untuk mencetak laba yang sebesar-besarnya dikemudikan hari.

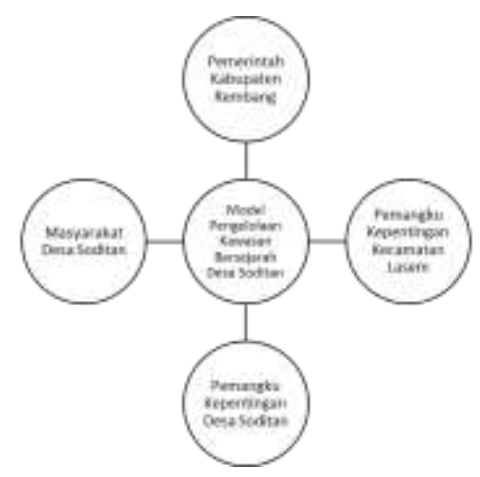

Gambar 3. Stakeholder Pengelola Kawasan Bersejarah Lasem di Bagian Soditan Lasem Sumber: Penulis, 2021

\section{KESIMPULAN}

Konsep manajemen pengelolaan kawasan bersejarah Desa Soditan diharapkan dapat mengoptimalkan peran kawasan bersejarah di Desa Soditan sebagai pariwisata dan juga sebagai cagar budaya yang dapat mendunia. Selain itu, konsep pengelolaan ini diharapkan dapat dipahami bersama dan dapat menjadi visi dari berbagai pemangku kepentingan. Adapun pemangku kepentingan yang memiliki visi sama adalah Pemerintah Kabupaten Rembang, dan masyarakat Desa Soditan. Untuk itu diperlukan sosialisasi sebagai upaya mendukung kawasan wisata dan cagar budaya kepada pemangku kepentingan, yaitu: Masyarakat Desa Soditan, dan pemangku kepentingan Desa Soditan, pemangku kepentingan Kecamatan Lasem, dan Pemerintah Kabupaten Rembang.

Tabel 1. Usulan Konsep Pengelolaan Kawasan Bersejarah di Desa Soditan Lasem Rembang

\begin{tabular}{lll}
\hline No & Konsep & Bangunan penting \\
& Pengelolaan & yang bisa dikelola \\
\hline 1. & BOT & Klenteng dan Lawang \\
& & Ombo, perdagangan \\
& dan jasa, wisata susur \\
& & sungai, Museum \\
& & Lasem, Hunian, \\
& & Koridor Kopi Lelet \\
\hline 2. & PCP & Homestay, simpul \\
& & transportasi lokal
\end{tabular}

Sumber: Analisis, 2021

\section{ACKNOWLEDGEMENT}

Terimakasih diberikan kepada anggota kelompok Studio Perancangan dan Pembangunan Kota Kelompok B5 PWK UNDIP Tahun 2021 yang telah menyusun Laporan Akhir Studio. Hasil studio ini merupakan bagian Pengabdian Masyarakat Mandiri FT UNDIP terkait Model Pengelolaan Kawasan Bersejarah di Desa Soditan Lasem Rembang tahun 20212041. 


\section{DAFTAR PUSTAKA}

BPPI Badan Pelestari Pusaka Indonesia (2019). Piagam Pelestarian Pusaka Saujana Indonesia, Indonesia Charter For Cultural Landscape Heritage Conservation.

ICOMOS, (1999). International Cultural Tourism Charter. Managing Tourism at Places of Heritage Significance. Adopted by ICOMOS at the 12th General Assembly in Mexico, October 1999.

Islami, M.R, Sivanca, G.A.A.N,Al Huda, F.M, Kartika, R.S., Pratama D.P., Elisa, D.N., Abdurrahman, Azlina, F.N., Arestu, P.R., Setia B, A.N., Putri, A.I., Manuel S., R., (2021). Laporan Akhir Desa Soditan Kecamatan Lasem Kabupaten Rembang. Studio Perancangan dan Pembangunan Kota. Prodi S1 PWK UNDIP Semarang.

Kusnawan, Muhammad Abi. (2011). Perekonomian Etnis Tionghoa Di Kota Lasem Tahun 1940-1950. Skripsi. Semarang: Universitas Negeri Semarang.

McKercher, B. dan Du Cros, H. (2002). Cultural Tourism: The Partnership Between Tourism and Cultural Heritage Management. Haworth Press, New York.

Menteri Pariwisata. (2018). Peraturan Menteri Pariwisata Republik Indonesia No.3 Tentang Petunjuk Operasional Pengelolaan Dana Alokasi Khusus Fisik Bidang Pariwisata. Jakarta.

Montgomery, J. (1998). Making a city: Urbanity, vitality and urban design. Journal of Urban Design, 3(1), 93-116. https://doi.org/10.1080/13574809808724418

Ng, S. L., \& Feng, X. (2020). Residents" sense of place, involvement, attitude, and support for tourism: A case study of Daming Palace, a cultural world heritage site. Asian Geographer,
37(2), 1-19. https://doi.org/10.1080/102257 06.2020 .1729212

NSW Heritage Office. (2004). State Agency Heritage Guide. Management of Heritage Assets by NSW Government Agencies .

Peraturan Bupati Rembang Nomor 47 Tahun 2019, tentang Rencana Tata Bangunan dan Lingkungan Kawasan Pusaka Lasem, Kecamatan Lasem Kabupaten Rembang.

Purwanto, MLF. (2018). Prosiding Temu Ilmiah Ikatan Peneliti Lingkungan Binaan Indonesia (IPLBI) 7, B 023-028. https://doi.org/ 10.32315/ti.7.b023

P Liu, S., \& Cheung, L. T. O. (2016). Sense of place and tourism business development. Tourism Geographies, 18(2), 174-193. https://doi.org/10.1080/14616688.2016.1149 513

Ramadhani, A., Faqih, M., \& Hayati, A. (2018). Inhabitant"s sense of place in the context of tourism kampung. Journal of Architecture \& Environment, 17(2), 151. https://doi.org/10. 12962/j2355262x.v17i2.a3894

Riclef, M., C. (1991). Sejarah Indonesia Modern. Yogyakarta: UGM Press 